\title{
Evaluation of the Phytochemicals and Antimicrobial Activities of the Ethanolic, Hexane and Ethyl Acetate Extracts of Spigelia Anthelmia Leaves
}

\author{
Uzama Danlami $^{1,}$,, Osuagwu Eberechi Cecilia ${ }^{2}$, Osuagwu Magnus Ifeanyi ${ }^{1}$ \\ ${ }^{1}$ Chemistry Advanced Research Centre, Sheda Science and Technology Complex, Garki, Abuja, Nigeria \\ ${ }^{2}$ Department of Forestry and Environmental Management, College of Natural Resources and Environmental Management, Micheal Okpara \\ University of Agriculture, Umudike, Umuahia, Nigeria
}

\section{Email address:}

uzamadan@yahoo.com (U. Danlami)

${ }^{*}$ Corresponding author

\section{To cite this article:}

Uzama Danlami, Osuagwu Eberechi Cecilia, Osuagwu Magnus Ifeanyi. Evaluation of the Phytochemicals and Antimicrobial Activities of the Ethanolic, Hexane and Ethyl Acetate Extracts of Spigelia Anthelmia Leaves. International Journal of Pharmacy and Chemistry.

Vol. 3, No. 3, 2017, pp. 29-32. doi: 10.11648/j.jppc.20170303.11

Received: September 3, 2016; Accepted: April 14, 2017; Published: May 6, 2017

\begin{abstract}
The objective of this study was to determine the phytoconstituents and antimicrobial activities of the hexane, ethanolic and ethyl acetate extracts of Spigelia anthelmia leaves. The phytochemical analysis was carried out using standard methods. The Agar well diffusion method was adopted in carrying out the antimicrobial screening. The results of the phytochemical analysis indicated the presence of saponins, tannins, steroids, terpenoids, resins and volatile oils in hexane extract; saponins, alkaloids, tannins and balsams in ethanolic extract and tannins, steroids, terpenoids and volatile oils in ethyl acetate extract. The antimicrobial screening indicated that the hexane extract was active on Escherichia coli, Salmonela typhi, Klebsiela pneumonia and Pseudomonas ariginosa but inactive on staphylococcus aureus. The ethanolic extract was active on all the test organisms. The ethyl acetate extract was active on Escherichia coli, Salmonella typhi, Klebsiella pneumonia and Pseudomonas ariginosa but inactive on staphylococcus aureus. This indicated that the hexane, ethanolic and ethyl acetate extracts of Spigelia anthelmia leaves can serve as potential antibiotics in ethno medicines.
\end{abstract}

Keywords: Klebsiela Pneumonia, Phytochemical Analysis, Tannins, Agar well Diffusion, Ethno Medicines

\section{Introduction}

Spigelia anthelmia is a genus of flowering plants in the family of Loganiaceae. The plant Spigelia anthelmia, also known as pinkroot, is a tropical annual weed [1].

The herb pinkroot, which forms the basis of the homeopathic remedy spigelia, is indigenous to the. United States and it has been used by the native Indians for ages as an anthelmintic much before the Europeans settlers arrived in America. Native American tribes used the weed's root for treating the body for intestinal parasites, such as round worm and tape worm [2].

It is also found in Nigeria, Senegal, Congo, Ethiopia, Indonesia, Asia, Canada, Ghana, Brazil, Jamaica, Costa Rica, Sri Lanka and Mexico [3].

Spigelia anthemia is not higher than 1 foot tall and it has feather lobed leaves with small purple flowers. The flowers are on one side of the spike and they open in the afternoon [4].

The plant is used for healing as a laxative, antibacterial, tremors, cancer, HIV, headache, throbbing pain, vermifuge, common cold, heartdiseases, chestpain, and reduce migraines. It is also used for toothache, foul mouth odour and fever. It is used to expel or destroy tapeworm and round worm in the body [5].

Spigelia anthelmia is used for chronic catarrh, difficulty in breathing that is eased when the patient lies on the right side keeping the head in an elevated position, fierce palpitations and even worms. Spigelia is an important remedy in pericarditis and other diseases of the heart. It is given to patients suffering from angina accompanied by constricting pains that spread into the chest, to one or both the arms and up to the throat. Homeopathic physicians also prescribe this medication to treat migraines, general headaches, sinus 
infections, neuralgic, rheumatic pains, particularly when the symptoms are bad on the left side of the body. The homeopathic remedy spigelia is prepared using the dehydrated aerial parts of the herb called pinkroot. Spigelia anthelmia when obtained freshly, has a disgusting smell that may cause a sedative effect when inhaled in an enclosed area. A study has been carried out to screen the extracts of Spigelia anthelmia for their Anthelmintic activity against experimental Nippostrongylusbraziliensis infection in rats. The study showed a progressive decrease in worm count with increasing dose [6].

A combination of the root of Spigelia anthelmia with Sennafennel to produce a strong formula to facilitate expulsion of worms from the body has been screened [2].

This study was aimed at determining the phytoconstituents and antimicrobial activities of the hexane, ethanolic and ethyl acetate extracts of Spigelia anthelmia leaves.

\section{Materials and Methods}

\subsection{Collection of Plant Material}

Spigelia anthelmia leaves were collected from Sheda Science and Technology Complex (SHESTCO), Sheda, Abuja, Nigeria. The plant was authenticated at the

Herbarium unit of the Department of Biological Sciences, Ahmadu Bello University, Zaria, Nigeria. The leaves were washed and dried for two weeks. This was then powdered using Excella mixer grinder and sieved with a mesh of size $0.5 \mathrm{~mm}$. The powdered samples were stored in clean air tight containers at ambient temperature until when needed for use.

\subsection{Preparation of Extracts}

Hexane, ethanol and ethyl acetate were used as the extraction solvents. $200 \mathrm{~g}$ of the powdered leaf sample was packed in a muslin cloth and inserted into the soxhlet extractor and hexane was used as the extraction solvent for a period of eight hours.

At the end of the period, the solvent was recovered by rotary evaporator.

Ethanol and ethyl acetate were also used as the extraction solvents for a period of another eight hours for each solvent. At the end of the periods, the solvents were recovered by rotary evaporator and the extracts were collected and allowed to cool in a desicator before they were analysed.

\subsection{Phytochemical Screening}

The phytochemical screening was carried out on the hexane, ethanol and ethylacetate extracts of the Spigelia anthelmia leaves $[7,8,9]$.

\subsubsection{Test for Steroids}

Acetic anhydride $(2 \mathrm{ml})$ was added to the extract $(0.5 \mathrm{~g})$, each with $2 \mathrm{ml}$ of $\mathrm{H}_{2} \mathrm{SO}_{4}$ (tetraoxosulphate(VI) acid). A colour change from violet to blue or green in some samples indicated the presence of steroids.

\subsubsection{Test for Terpenoids}

The extract $(0.2 \mathrm{~g})$ of the whole plant sample was mixed with chloroform $(2 \mathrm{ml})$ and concentrated tetraoxosulphate(VI) acid (3 ml) was carefully added to form a layer. A reddish brown colouration of the inner face indicated the presence of terpenoids.

\subsubsection{Test for Flavonoids}

The extracts $(0.2 \mathrm{~g})$ were treated with of tetraoxosulphate(VI) acid $(5 \mathrm{ml})$. The formation of an orange colour indicated the presence of flavonoids.

\subsubsection{Test for Phenols}

Ferric chloride test: Extracts $(0.2 \mathrm{~g})$ were treated with ferric chloride solution $(5 \mathrm{ml})$. Formation of bluish black colour indicated the presence of phenol.

\subsubsection{Test for Saponins}

The extract $(0.2 \mathrm{~g})$ was shaken with distilled water $(5 \mathrm{ml})$. Formation of frothing, appearance of creamy mist of small bubbles, indicated the presence of saponins.

\subsubsection{Test for Quinone}

The Extracts $(0.2 \mathrm{~g})$ were treated with tetraoxosulphate(VI) acid $(5 \mathrm{ml})$. The Formation of orangecolour indicated the presence of quinone.

\subsubsection{Test for Tannins}

Each portion of plant extracts (5 g) was stirred with distilled water $(10 \mathrm{ml})$, Filtered and ferric chloride reagent added to the filtrate. A blue- green precipitate was taken as evidence for the presence of tannins.

\subsubsection{Test for Anthraquinones Derivatives}

The powdered leaves $(3 \mathrm{~g})$ was taken in a dry test tube and chloroform $(10 \mathrm{ml})$ was added.

The mixture was shaken for 5 minutes. The extract was filtered and an equal volume of ammonia solution $(10 \mathrm{ml})$ was added to the filtrate and shaken. A non bright pink colouration in the upper aqueous layer indicated the presence of free anthraquinones.

\subsection{Antimicrobial Screening}

\subsubsection{Source of Test Organisms}

The pure culture of clinical isolates of bacteria includes Salmonella typhi, Staphylococcus aureus, Escherichia coli, Pseudomonas aeriginosa and Klebsiella pneumonia.

They were obtained from University of Abuja Teaching Hospital, Gwagwalada, Abuja, Nigeria.

\subsubsection{Antibacterial Activities of the LeavesExtracts}

The activities of hexane, ethanolic and ethyl acetate extracts of Spigeliaanthelmialeaves were evaluated on bacterial isolates which includes: Salmonella typhi, Staphylococcus aureus, Escherichia coli, Pseudomonas aeriginosa, and Klebsiella pneumonia using agar well diffusion method [7, 10]. The bacteria isolates were allowed to grow on Mueller Hinton Broth (MHB) for 24 hours at $37^{\circ} \mathrm{C}$. The bacterial spores were harvested after sporulation by pouring a mixture sterile 
glycerol and distilled water to the surface of the plate and later scraped the spores with sterile glass rod. The bacterial isolates suspension were standardized to an Optical Density (OD) 600 $\mathrm{nm}$ of 0.5 using spectrophotometer before use. $0.2 \mathrm{ml}$ of the standardized bacterial suspension was evenly spread on Mueller Hinton Agar (MHA) using a glass spreader. Wells were then bored into the agar media using a sterile $6 \mathrm{~mm}$ cork borer, the wells were filled up with $0.2 \mathrm{ml}$ of the various concentration of the extract $(1000,500$ and $250 \mathrm{mg} / \mathrm{ml}$ ), certain precaution was taken to avoid spillage of the suspension to the surface of the agar medium. The plates were allowed to stand in the lamina flow hood (safety cabinet) for 30 seconds to allow proper diffusion of the extract [11]. The Bacteria plates were incubated at $37^{\circ} \mathrm{C}$ for $24 \mathrm{hrs}$. Chloramphenicol was prepared $(10 \mu \mathrm{g} / \mathrm{ml})$ which served as a positive control and DMSO (Dimethyl sulfoxide) served as a negative control. The inhibition zones were measured in millimetre at the end of the incubation period. The study was carried out in triplicates and the mean values were calculated with the standard deviations.

\section{Results and Discussions}

\subsection{Phytochemical Analysis}

The phytochemical analysis result is shown in Table 1. This revealed the presence of saponins, tannins, steroids, terpenoids, resins and volatile oils in hexane extracts.

Saponins, alkaloids, tannins and balsams were present in the ethanolic extract while Tannins, steroids, terpenoids, resins and volatile oils were present in the ethyl acetate extract.

The alkaloids detected in the leaf extract possess medicinal properties. The saponins present in the leaf extract exhibit cytotoxic effect and growth inhibition against a variety of cells, making them to possess anti-inflammatory and anticancer properties. They also show tumour inhibiting activity on animals [12].

Table 1. Phytochemical analysis of the leaves of Spigelia anthelmia in different solvent extracts.

\begin{tabular}{|c|c|c|c|}
\hline Phytochemical Constituent & Hexane extract & Ethanol extract & Ethyl acetate \\
\hline Saponin. & + & + & - \\
\hline Alkaloids. & - & + & - \\
\hline Flavonoids. & - & - & - \\
\hline Tannins. & + & + & + \\
\hline Steroids. & + & - & + \\
\hline Terpenoid. & + & - & + \\
\hline Phlobatanin. & - & - & - \\
\hline Resins. & + & - & + \\
\hline Balsams. & - & + & - \\
\hline Volatile oils. & + & - & + \\
\hline
\end{tabular}

+ means present,- means absent

\subsection{Antimicrobial Screening}

The results of the antimicrobial activities of the leaf extracts of the Spigelia anthelmia are given in Table 2. The results revealed that the extracts have a potent antimicrobial activities against Escherichia coli, Klebsiella pneumonia, Salmonella typhi, Pseudomonas aeriginosa and Staphylococcus aureus. The antimicrobial activity was screened from the zone of inhibition.

The inhibitory effect of the extracts were compared with standard antibiotics like Chloramphenicol.

The ethanolic, ethylacetate and hexane extracts showed significant inhibitions against the test organisms at $1000 \mathrm{mg} / \mathrm{ml}$ which was comparable with that of the standard $(10 \mu \mathrm{g} / \mathrm{ml})$ used [13].

At $500 \mathrm{mg} / \mathrm{ml}$ of the extracts, only the ethanolic and ethyl acetate extracts showed significant inhibition against the test organism, while at $250 \mathrm{mg} / \mathrm{ml}$ of the extracts, only the ethanolic extract showed significant inhibition against the test organisms.

This showed that the activities of the extracts are concentration dependent. The activities increase as the concentration increases. Only ethanolic extract was active with staphylococcus aureus.

At $250 \mathrm{mg} / \mathrm{ml}$ of the extracts only the ethanolic extract was active with Escherichia coli and Salmonella typhi.

At $500 \mathrm{mg} / \mathrm{ml}$ of the extracts the hexane extract was not active with any of the organisms. The ethyl acetate was active with only Escherichia coli and Pseudomonas aeriginosa. The ethanolic extract was active with all the organisms except staphylococcus aureus [14, 15].

At $1000 \mathrm{mg} / \mathrm{ml}$ of the extracts, the ethanolic extract was active with all the organisms. The ethyl acetate and hexane extracts were also active with all the organisms except Staphylococcus aureus. This showed that the activities of the extracts increase with an increase in the concentration of the extracts.

It was observed that the leaf extracts were more active at concentration $250 \mathrm{mg} / \mathrm{ml}, 500 \mathrm{mg} / \mathrm{ml}$ and $1000 \mathrm{mg} / \mathrm{ml}$, that is why these concentrations were chosen for the antimicrobial screening. 
Table 2. The antimicrobial screening of Spigelia anthelmia leaf extracts on clinical isolates.

\begin{tabular}{|c|c|c|c|c|c|c|c|c|c|c|c|}
\hline \multirow[t]{2}{*}{ Test Organism } & \multicolumn{9}{|c|}{ Extract concentration $(\mathrm{mg} / \mathrm{ml})$} & \multirow{3}{*}{$\begin{array}{l}\text { P.C. } \\
\text { CLP } \\
\end{array}$} & \multirow{2}{*}{$\begin{array}{l}\text { N.C } \\
\text { DMSO } \\
\end{array}$} \\
\hline & Ethyl & & & Hexa & & & Ethan & & & & \\
\hline & 1000 & 500 & 250 & 1000 & 500 & 250 & 1000 & 500 & 250 & & \\
\hline 1. E.coli. & 10.00 & 8.00 & - & 9.00 & - & - & 13.00 & 11.00 & 9.00 & 20.00 & NA \\
\hline 2. S. typhi. & 8.00 & - & - & 8.00 & - & - & 11.00 & 11.00 & 8.00 & 20.00 & - \\
\hline 3. K.pneumonia. & 8.00 & - & - & 8.00 & - & - & 9.00 & 8.00 & - & 20.00 & - \\
\hline 4 P.areginosa. & 9.00 & 8.00 & - & 7.00 & - & - & 9.00 & 7.00 & - & 20.00 & - \\
\hline 5. S.aureus. & - & - & - & - & - & - & 9.00 & - & - & 23.00 & - \\
\hline
\end{tabular}

CLP - Chloramphenicol (10.00, DMSO - Dimethylsulphoxide,

P.C. - Positive control, N.C. - Negative control.NA-No activity

\section{Conclusion}

The ethanolic leaf extract of Spigelia anthelmia can serve as a potential source of antibacterial. The leaves of Spigelia anthelmia can be used as ethno medicine.

\section{References}

[1] Nathaniel L. B. and Addison B. (2015). An illustrated flora of the Northern United States, Canada and the British possessions. The plant list. Retrieved 2015.

[2] Alex V. P., Katherine G. M., Jose C. M. S., Carmen M. M. and Lena S. (2011). Spigeliagenuflexa, phytokeys, 6:47-65.

[3] Neuwinger H. D. 2000. African traditional medicine: a dictionary of plant Use and applications. Med pharm. Scientific, Stuttgart, Germany, pp:589.

[4] Olorunfemi C. J., Joseph O. A., Ambrose O. A. and Rowland I. S. A. (2006). Anthelmintic efficacy of extracts of Spigelia anthelmintic of extracts of Spigelia anthelmia Linn on experimental Nippostrongylusbraziliensis in rats, J. Vet. Sc. 7(3): 229-232.

[5] Okwu D. E. (2001). Evaluation of the Chemical Composition of Indigenous Spices and Flavouring Agents. Global J. Appl. Sci. 7(3): 455-459.

[6] Uzama D. (2009). Phytochemical screening and antibacterial activity of Guava (Psidium guajava L.) crude extracts. Bio. Env. Sc. J. Trop. 6(4):139-142.
[7] Sofowora L. A. Medicinal plants and traditional medicine in Africa. Spectrum Books Ltd., Ibadan, Harbone. 1993; 55-71.

[8] Esimone C. O., Adiku M. U. and Okonta J. M. (1998). Preliminary Antimicrobial screening of the ethanolic extract from the Lichen Usnea Subfloridans (L.). J. Pharmaceutic. Res. Dev. 3(2):99-102.

[9] Nwaogu L. A., Ujuwundu C. O. and Mgbemena A. I. 2000. Studies on the Nutritional and phytochemical composition of Amaratus hybridus leaves. Bis-Res. 4:28-31.

[10] Evans, W. C. and Trease, G. E. (2002). Pharmacognosy, $15^{\text {th }}$ Ed. London: Saunders publishers. pp 42- 44, 246-249, 304306, 331-332.

[11] Brain, K. R. and Tuner (1975). The practical evaluation of phytochemistry pharmaceuticals. Wright science chila Bright. pp. 120-140.

[12] Uzama D., Bwai M. D. and Thomas S. A. (2012). The phytochemical, proximate and elemental analyses of Securinega virosa leaf extracts, Research J. in Engg and Applied Sciences. 1(6):351- 354.

[13] Adeyeyi E. I. and Okokiti M. K. O. (1999). Proximate composition andsome nutritional valuable mineral of two varieties of Capsicum annum (Bell and Cherry peppers). Discovery Innovation. 11:75 - 81.

[14] Akindahunsi A. A. and Salawu S. O. (2005). Phytochemical screening and nutrient-antinutrient composition of selected tropical green leafy vegetables. Afr. J. Biotech. 4:497-501.

[15] Antia B. S., Akpan E. J., Okon P. A. and Umoren U. I. (2006). Proximate composition and phytochemical constituents of leaves of some acalypha species. Park J. Nutri. 5:166-168. 